\title{
Assessment of Probiotic and Neutraceutical Properties of Camel Milk Yoghurt
}

\author{
Lokesh Tak $^{1 *}$, Basant Bais ${ }^{1}$, Raghvendar Singh ${ }^{2}$, Sanjay Singh $^{1}$ and T.C. Nayak ${ }^{3}$
}

${ }^{1}$ Department of Livestock Products Technology, College of Veterinary and Animal Science, Rajasthan University of Veterinary and Animal Sciences, Bikaner, Rajasthan-334001, India

${ }^{2}$ National Research Centre on Camel, Bikaner, Rajasthan-334001, India

${ }^{3}$ Department of Veterinary Clinical Medicine, Ethics and Jurisprudence, College of

Veterinary and Animal Science, Rajasthan University of Veterinary and Animal Sciences, Bikaner, Rajasthan-334001, India

*Corresponding author

\section{A B S T R A C T}

In present generation, stress is considered as the root cause for development and progression of many diseases due to oxidative damage of the health. Supplementation of exogenous antioxidants from food substance has a promising approach to combat or act as shield against it. Probiotics can be define as the food substance which contain

Keywords

Camel milk,

Neutraceutical properties,

Functional food,

Fermentative potential,

Lactobacillus fermentum

Article Info

Accepted:

24 September 2018

Available Online:

10 October 2018 microorganisms that are claimed to provide health benefits when consumed directly, whereas neutraceutical food are the food or part of a food which allegedly provides medicinal or health benefits, including the prevention and treatment of disease. In the present study, probiotic and neutraceutical properties of fermented camel milk yoghurt were studied to determine the potential health benefits. The lactic acid bacteria (LAB) itself act as probiotic and considered as "good gut micro-flora". The bioactive peptides which are produced by fermentation of camel milk have anti-oxidant nature. in the study, Evaluation of the product have been done for change in $\mathrm{pH}$, TA, anti-oxidant activity (\% inhibition of ABTS and DPPH activity), rancidity formation (TBA value) and microbiological parameters like Plate count, Coliform count, Yeast-Mold count and MRS count. The fermentative reactions was created using lactic acid bacteria (LAB); Lactobacillus fermentum. The organism shows vitality at day 7 of storage, which evinces the probiotic nature of the yoghurt. The study expresses the highest functional properties of the yoghurt in fresh conditions. It reveals that during storage, it diminished in terms of its functional potential.

\section{Introduction}

Camel plays a vital role in arid and semi-arid area by virtue of their adaptability and it concerned as an important component of Indian fragile desert ecosystem. However, their contribution as dairy animals is less substantial but the camel milk act as piety due to its functional properties and neutraceutical values (Al-Shamsi et al., 2018). The onehumped camels (Camelus dromedarius) are well-known producers of milk in the family 
camelidae. The composition and technofunctional properties of camel milk have contrast from bovine milk due to the composition and structure of its protein content. It is widely admitted that the milk of dromedary camels have very good quality than other species in an environment the antioxidative properties in terms of fermentative potential (Singh et al., 2018).

Normal camel milk is opaque and foamy nature. The taste of camel milk is usually sweet, when camels are fed on green fodder, but sometimes salty, due to feeding on certain shrubs and herbs in the arid regions (Yadav et al., 2015).

The milk fat of camel milk mainly contains poly unsaturated fatty acids (PUFA). These polyunsaturated fatty acids are very essential to human nutrition. The content of long chain fatty acid (C-14 to C-18) is higher than short chain fatty acid (C-4 to C-14) (Narmuratova et al., 2006). Caseins (CNs) are the major proteins in camel milk, and $\alpha-, \beta-$ and $\kappa-\mathrm{CN}$ constitutes about 65,21 and $3.47 \%$ respectively, of total caseins (Kappeler et al., 2003). Camel milk shows similarity to human milk as it contains a high amount of $\beta-\mathrm{CN}$; this could reflect its higher digestibility and lower incidence of allergy in infants, as $\beta-\mathrm{CN}$ is more sensitive to peptic hydrolysis than $\alpha$ CN (El-Agamy et al., 2009). Camel milk $\alpha-$ lactalbumin was reported to have a molecular weight of $14.6 \mathrm{kDa}$ having 123 residues, which is similar to that of bovine, human and goat milk (Beg et al., 1985).

Production of bioactive peptides can be done by controlled biochemical reactions like enzymatic hydrolysis and/or fermentative reactions by lactic acid bacteria (LAB). Bioactive peptides have been defined as specific protein fragments that have a positive impact on body functions or conditions and may ultimately influence health (Kitts and
Weiler, 2003). These are synthesised in the cell in the form of large prepropeptides, which are then cleaved and modified to give active products. Milk derived bioactive peptides play vital roles in human health and nutrition. They act as functional food and carry various neuraceutical properties (Haque et al., 2008). Bioactive Peptides derived from the milk of camel exert multifunctional properties, including anti-microbial, immune modulatory, anti-oxidant, inhibitory effect and antagonistic activities against various toxic agents (Agarwal et al., 2003).

Milk fermentation by proteolytic lactic acid bacteria $(\mathrm{LAB})$ is one of the economical and practical methods for the production of fermented dairy products enriched in bioactive peptides (Hayes et al., 2007). Lactobacillus fermentum is one of the keynote species of genus Lactobacillus which are used for a wide variety of applications; these applications include food and feed fermentation. It has been found that some strains for Lactobacillus fermentum have natural resistance to certain antibiotics and chemotherapeutics. They are considered potential vectors of antibiotic resistance genes from the environment to humans or animals to humans. Lactobacillus fermentum ME-3; an anti-oxidative lactobacilli showed very attractive probiotic nature on goat's milk (Kullisaar et al., 2003). In the present research, the anti-oxidant potential and storage capacity of the camel milk fermented by Lactobacillus fermentum has been carried out.

\section{Materials and Methods}

\section{Chemical and reagents}

Fine chemicals such as ABTS (2,2'-azinobis (3-ethylbenzthiazoline-6-sulphonic acid), DPPH (2,2'-diphenyl-1-picrylhydrazyl), Potassium persulphate $\left(\mathrm{K}_{2} \mathrm{~S}_{2} \mathrm{O}_{8}\right)$, Tris- $\mathrm{HCl}$ were purchased from Sisco Research 
Laboratories (SRL) Pvt. Ltd., India and TBA (2-Thiobarbituric acid) was obtained from Merck Life Science Private Limited, India. Other chemicals were of analytical grade from reputed companies and used without further purification. All solutions, prepared with double-distilled water, were kept at $4^{\circ} \mathrm{C}$ before further use.

\section{Collection of samples}

About 2 liter of fresh camel milk was collected from camels maintained under the Camel Dairy at National Research Center on Camel (ICAR-NRC on Camel), Bikaner at weekly interval for period of 2 months to perform the different experiments as mentioned under the study. The milk was further inoculated with Lactobacillus fermentum and incubated for 8 hours for optimum functional properties to form bioactive peptide rich yoghurt.

\section{pH and Titratable Acidity measurement}

The $\mathrm{pH}$ of samples was measured using combined glass electrode of Milkoscan at camel milk research laboratory, ICAR-NRC on Camel, Bikaner.

The $\mathrm{pH}$ of each sample was measured just before heating to inactivate the residual enzyme. Titratable acidity expressed as percentage of lactic acid, was determined by $10 \mathrm{ml}$ of each sample titrating with $0.1 \mathrm{~N}$ $\mathrm{NaOH}$ using phenolphthalein as an indicator to an end-point of faint pink color.

\section{DPPH (2，2'-diphenyl-1-picrylhydrazyl) radical-scavenging activity}

The $\%$ inhibition activity of 2, 2'-diphenyl-1picrylhydrazyl (DPPH) was estimated following the method of Brand-Williams et al., (1995), with slight modification. The concentration of DPPH reagent was 100 which were mixed with $0.1 \mathrm{M}$ molar buffer solution of Tris- $\mathrm{HCl}(\mathrm{pH}$ 7.4). The hydrolysate of fermented camel milk was obtained after centrifugation at $10000 \mathrm{rpm}$ for 10 minutes at $4{ }^{\circ} \mathrm{C}$. The hydrolysate of fermented camel milk was analysed for DPPH activity. The absorbency was measured in zero minute $\left(\mathrm{At}_{0}\right)$ and in 20 minute $\left(\mathrm{At}_{20}\right)$ at 517 nanometer $(\mathrm{nm})$ using a spectrophotometer. Ethanol was used as blank. The free radical-scavenging activity was calculated from the following equation:

DPPH activity $(\%$ inhibition $)=100-$ [( $\left.\left.\mathrm{At}_{20} / \mathrm{At}_{0}\right) \times 100\right]$

(Where, $\mathrm{At}_{0}=$ absorbency in zero minute and $\mathrm{At}_{20}=$ absorbency in 20 minute)

\section{ABTS (2, 2' ethylbenzthiazoline-6-sulphonic acid) radical-scavenging activity}

The \% inhibition of ABTS activity was analysed according to method of Salami et al., (2009) with slight modifications. The stock solution of ABTS was formed with $2.45 \mathrm{mM}$ potassium persulphate $\left(\mathrm{K}_{2} \mathrm{~S}_{2} \mathrm{O}_{8}\right)$ and kept in the dark place at room temperature for 16 hours before use. Prior to use, the stock solution was diluted with distilled water to get an absorbance of 0.70 at zero minute.

The hydrolysate of fermented camel milk was obtained after centrifugation at $10000 \mathrm{rpm}$ for 10 minutes at $4{ }^{\circ} \mathrm{C}$ and used for $\%$ inhibition activity of ABTS. The absorbance was measured after $20 \mathrm{~min}\left(\mathrm{At}_{20}\right)$ at 734 nenometer (nm) using spectrophotometer. The ABTS activity was calculated by using the following formula:

ABTS activity $(\%$ inhibition $)=\left[\left(0.7-\mathrm{At}_{20}\right) /\right.$ 0.7] x 100

(Where, $\mathrm{At}_{20}=$ absorbency in twenty minute) 


\section{TBA (2-Thio Barbituric Acid) value}

The TBA value was determined according to Witte et al., (1970) with slight modification. The filtrate was obtained using $20 \%$ trichloroacetic acids (TCA) in $2 \mathrm{M}$ orthophosphoric acid and filtered through Whatman no.1 filter paper. The filtrate was then mixed with fresh chilled 2-thiobarbituric acid $(0.005 \mathrm{M}$ in $0.05 \mathrm{M} \mathrm{NaOH})$. The test tube was shaken well and placed in the dark at room temperature $\left(25^{\circ} \mathrm{C}\right)$ for $15-17$ hour to develop the color reaction. Formation of blank take place by mixing $3 \mathrm{ml}$ of fresh chilled 2thiobarbituric acid $(0.005 \mathrm{M}$ in $0.05 \mathrm{M} \mathrm{NaOH})$ with $1.5 \mathrm{ml}$ of cold solution containing $20 \%$ trichloroacetic acids in $2 \mathrm{M}$ orthophosphoric acid and $1.5 \mathrm{ml}$ of distilled water. After 15- 17 hour colour reactions was measured by spectrophotometer at $532 \mathrm{~nm}$ (A532). The TBA value was expressed as $\mathrm{mg}$ MDA $/ \mathrm{kg}$ of sample, which was calculated by multiplying the absorbance by 5.2 factors as follows:

TBA value $(\mathrm{mg}(\mathrm{MDA}) / \mathrm{kg})=\mathrm{A} 532 \times 5.2$

\section{Microbial count}

Microbial count was determined by using pour plate method. Standard plate count (SPC) was determined with plate count agar medium and the plates of different dilutions were incubated at $37^{\circ} \mathrm{C}$ for 24 hour. Violet Red Bile (VRB) Agar medium was used for determination of coliform bacteria. Man, Rogosa and Sharpe (MRS) agar medium used for enumeration and cultivation of Lactobacillus species and by pour plate method. Yeast molds (Y-M) count take place by Potato dextrose agar (PDA) medium by pour plate method.

\section{Statistical analysis}

All the experiments of fermentation study were repeated three times and samples were drawn in duplicate. Data collected during the present investigation were subjected to statistical analysis by using F-test and adopting appropriate methods of analysis of variance as described by Snedecor and Chochran (1994). Wherever, the variance ratio were found significant at 5 per cent and highly significant at 1 per cent levels of probability, the significance of mean differences were tested by Duncan's New Multiple Range Test (Duncan's Range Test) as modified by Kramer (1957).

\section{Results and Discussion}

Table 1 illustrates changes in various biochemical properties of camel milk yoghurt during storage at $4^{\circ} \mathrm{C}$ for different periods. The results revealed that the stability of camel milk yoghurt decreased day by day with the storage period. Moreover, the good microbial load (MRS count) of the yoghurt decreased significantly during the whole storage period. However initially coliform count and yeastmold (Y-M) count remains nil which show hygienic production of the products. Changes in $\mathrm{pH}$ and acidity of the products during storage, suggests effect of yoghurt microflora on its nutrient composition. Similar changes were observed by Eissa et al., (2010), in goat milk yoghurt. Camel milk yoghurt shows an increased trend in acidity whereas it show continuous fall in $\mathrm{pH}$ during storage period.

According to Valli and Traill (2005), the activity and growth rate of the starter cultures are strain dependent. Hence, the acidification rate of lactic acid bacteria varied with the type of milk, being some yoghurt starters more active than others. Table 1 Shows changes in total viable count (plate count) of camel yoghurt during storage. The results obtained revealed that camel milk yoghurt contained highest total viable cells of bacteria initially. Increase in acidity of the growth media in camel milk yoghurt may retard bacterial growth. 
Table.1 Storage study (Mean \pm SE) of fermented camel milk product

\begin{tabular}{|c|c|c|c|c|}
\hline Parameter & Day 1 & Day 3 & Day 5 & Day 7 \\
\hline TBA $* *$ & $0.006^{\mathrm{a}} \pm 0.0001$ & $0.12^{\mathrm{b}} \pm 0.002$ & $0.16^{\mathrm{c}} \pm 0.002$ & $0.29^{d} \pm 0.025$ \\
\hline $\mathrm{pH}^{\mathrm{NS}}$ & $4.5 \pm 0.02$ & $4.30 \pm 0.01$ & $4.16 \pm 0.01$ & $4.02 \pm 0.01$ \\
\hline $\mathrm{TA}^{\mathrm{NS}}$ & $0.68 \pm 0.010$ & $0.78 \pm 0.005$ & $0.89 \pm 0.005$ & $1.10 \pm 0.010$ \\
\hline ABTS*** & $20.15^{\mathrm{d}} \pm 0.45$ & $19.55^{\mathrm{c}} \pm 0.09$ & $15.05^{\mathrm{b}} \pm 0.19$ & $13.12^{\mathrm{a}} \pm 0.03$ \\
\hline DPPH** & $8.15^{\mathrm{d}} \pm 0.02$ & $7.80^{c} \pm 0.04$ & $5.05^{b} \pm 0.22$ & $3.15^{\mathrm{a}} \pm 0.04$ \\
\hline $\begin{array}{c}\text { Coliform } \\
\text { count*** } \\
\log (\text { CFU } / m l) \\
\end{array}$ & nil & nil & $1.42^{\mathrm{a}} \pm 0.3$ & $1.64^{\mathrm{b}} \pm 0.4$ \\
\hline $\begin{array}{c}\text { Yeast Mold } \\
\text { count*** } \\
\log (\text { CFU } / m l)\end{array}$ & nil & nil & nil & $0.78 \pm 0.1$ \\
\hline $\begin{array}{l}\text { Plate count***; } \\
\log (\mathrm{CFU} / \mathrm{ml})\end{array}$ & $9.47^{\mathrm{d}} \pm 0.8$ & $9.35^{\mathrm{c}} \pm 0.8$ & $9.18^{b} \pm 0.7$ & $8.85^{a} \pm 0.6$ \\
\hline $\begin{array}{l}\text { MRS count" } \\
\log (\text { CFU/ml })\end{array}$ & $9.21^{\mathrm{d}} \pm 0.4$ & $9.15^{\mathrm{c}} \pm 0.7$ & $9.07^{b} \pm 0.5$ & $9.01^{\mathrm{a}} \pm 0.8$ \\
\hline
\end{tabular}

Note - Means bearing different superscripts differ significantly.

$* *=$ Significant at $1 \%(\mathrm{P}<0.01), *=$ Significant at $5 \%(\mathrm{P}<0.05), \mathrm{NS}=$ Non Significant

The results obtained agree with the findings of Masud et al., (1991). Lactobacillus count (MRS count) in camel milk yoghurt was decreased significantly during storage.

The load of lactic acid bacteria, however found in yoghurt at day 7 of storage, which stated as both yoghurts have probiotic nature. Tamime and Robinson (1999) reported that yoghurt should contain as minimum as 7 $\log (\mathrm{cfu} / \mathrm{ml})$ or $10^{7}$ viable cells of lactic acid bacteria per $\mathrm{ml}$, to be stated as probiotic.

The change in chemical composition and lactic acid bacteria show parity with the results demonstrated by Ismaili et al., (2017).

On the other hand, yeasts and molds were steadily increased significantly in camel milk yoghurt with storage period of day 7 but not found at day 1 to day 5 of storage period. An increase in acidity and/or reduction in potential oxygen during fermentation process may provide suitable state for growth of yeasts and molds. Contamination by yeasts and molds during processing of yoghurt was reported by Karleskind et al., (1993).

Coliforms were absent in fresh camel yoghurt, Coliforms viable cells were detected in camel yoghurt from 5 days of storage and increased significantly at 7 day of storage, which may be due to contamination or any other reason. However, many workers reported on the survival of coliforms, if present, in yoghurt to a maximum of 3 days, shown by Karleskind et al., (1993).

Moreover, E. coli was observed by El-Agamy et al., (1996) and Mainfreni et al., (2002), to survive the low $\mathrm{pH}$ domestic yoghurt developed during cold storage and could tolerate lower acidity up to 6 days.

Usually, lipid per oxidation is not a major problem in yoghurt due to the low $\mathrm{pH}$, the low storage temperature and low permeability to oxygen of packaging materials. Furthermore when lactobacilli are used as starter culture, it helps to reduce the rate of 
lipid peroxidation by its natural anti-oxidant potential. Lipid peroxidation of camel milk products was determined by Thio Barbituric Acid (TBA) value, which gave the idea about rancidity of both milk products. In both products the initial TBA value at day 1 was very low and it slowly increased at day 3 and day 5 of storage which showed slow elevation till day 7 of storage, it increased significantly but the value was lower than 1 which can give an idea about no foul smell till 7 day of storage of camel milk product.

The results led to similar conclusion as provided by Saide and Gilliland (2005) that lactobacilli as a starter culture was helpful to prevent lipid per oxidation due to its antioxidant potential, however elevation of TBA value during storage was due to change in its physico chemical as well as microbial properties.

\section{Acknowledgement}

Staff members of National Research Centre on Camel, Bikaner, Rajasthan, India 334001

\section{References}

Agarwal RP, Swami SC, Beniwal R, Kochar DK, Sahani MS, Tuteja FC, Ghouri SK (2003). Effect of camel milk on glycemic control, risk factors and diabetes quality of life in type-1 diabetes: A randomized prospective controlled study. Journal of Camel Practice and Research 1; 10(1):4550.

Al-Shamsi KA, Mudgil P, Hassan HM, Maqsood S (2018). Camel milk protein hydrolysates with improved technofunctional properties and enhanced antioxidant potential in in vitro and in food model systems. Journal of Dairy Science. 1; 101(1):47-60.

Beg, O. U., Bahr- Lindström, H., Zaidi, Z. H., and Jörnvall, H. (1985). The primary structure of $\alpha$ - lactalbumin from camel milk. European Journal of Biochemistry 147(2): 233-239.

Brand-Williams, W., Cuvelier, M. E., and Berset, C. L. W. T. (1995). Use of a free radical method to evaluate antioxidant activity. LWT-Food Science \& Technology, 28(1): 25-30.

Eissa, E.A., Ahmed, I.M., Yagoub, A.E.A. and Babiker, E.E. (2010). Physicochemical, microbiological and sensory characteristics of yoghurt produced from goat milk. Livestock Research for Rural Development 22(8): 281-286.

El-Agamy EI, Ruppanner R, Ismail A, Champagne C.P. and Assaf, R. (1996). Purification and characterization of lactoferrin, lactoperoxidase, lysozyme and immunoglobulin's from camel's milk. International Dairy Journal 6: 129145.

El-Agamy, E. I., Nawar, M., Shamsia, S. M., Awad, S., and Haenlein, G. F. (2009). Are camel milk proteins convenient to the nutrition of cow milk allergic children? Small Ruminant Research 82(1): 1-6.

Haque, E., Chand, R., and Kapila, S. (2008). Biofunctional properties of bioactive peptides of milk origin. Food Review International 25(1): 28-43.

Hayes, M., Stanton, C., Fitzgerald, G. F., and Ross, R. P., (2007). Putting microbes to work: dairy fermentation, cell factories and bioactive peptides. Part II: bioactive peptide functions. Biotechnology Journal 2(4): 435-449.

Ismaili MA, Hamama A, Saidi B, Zahar M, Meryem A (2017). Chemical Composition, Microbial Profile and Identification of Lactic Acid Bacteria of Moroccan Fermented Camel Milk "Lfrik". Current Research for Nutrition and Food Science Journal 24; 5(3): 38390.

Kappeler, S. R., Farah, Z., and Puhan, Z. (2003). 5'-Flanking regions of camel milk genes are highly similar to homologue regions of other species and can be divided into two distinct groups. Journal of Dairy Science 86(2): 498-508. 
Karleskind, D., Laye, I. and Morr. F.V. (1993). Chemical, biological and sensory properties of plain non-fat yoghurt. Journal of Food Science 58: 991-995.

Kitts, D. D., and Weiler, K. (2003). Bioactive proteins and peptides from food sources. Applications of bioprocesses used in isolation and recovery. Current Pharmacology Design 9(16): 1309-1323.

Kramer, C.Y. (1957). Extension of multiple range tests to group correlation adjusted means. Biometrics 13: 13.

Kullisaar, T., Songisepp, E., Mikelsaar, M., Zilmer, K., Vihalemm, T., and Zilmer, M. (2003). Antioxidative probiotic fermented goats' milk decreases oxidative stressmediated atherogenicity in human subjects. British Journal of Nutrition 90(02): 449-456.

Mainfreni M., Marino M., Pittia P., and Rondinini G. (2002). Textural and sensorial characterization of Montasio cheese produced using proteolytic starters. Milchwissenchaft 57: 23-26.

Masud, T., Sultana, K. and Shah, M.A. (1991). Incidence of lactic acid bacteria isolated from indigenous dahi. Australian Journal of Animal Science, 4: 329-331.

Narmuratova, M., G. Konuspayeva, G. Loiseau, A. Serikbaeva, B. Natalie, M. Didier and F. Bernard (2006). Fatty acids composition of dromedary and Bactrian camel milk in Kazakhstan. Journal of Camel Practice and Research 13(1): 4550 .

Saide, J. A. O., and Gilliland, S. E. (2005). Antioxidative activity of lactobacilli measured by oxygen radical absorbance capacity. Journal of Dairy Science 88(4): 1352-1357.

Salami, M., Yousefi, R., Ehsani, M. R., Razavi, S. H., Chobert, J. M., Haertlé, T. and Moosavi-Movahedi, A. A. (2009). Enzymatic digestion and antioxidant activity of the native and molten globule states of camel $\alpha$-lactalbumin: Possible significance for use in infant formula. International Dairy Journal 19(9): 518523.

Singh S, Bais B, Singh R, Tak L, Gorachiya PR, Kumari R (2018). Determination of the bioactive potential (Antioxidant activity) of camel milk during fermentation process. Journal of Camel Practice and Research 25(1):131-4.

Snedecor, G.W. and Cochran, W.G. (1994). Statistical methods, $8^{\text {th }} \mathrm{Edn}$. The Iowa State University Press, Ames, Iowa, U.S.A.

Tamime, A. Y. and Robinson, R. K. (1999). Yoghurt science and technology. Cambridge, UK: Woodhead Publishing Ltd. pp, 640.

Valli C. and Traill W. B. (2005). Culture and food: A model of yoghurt consumption in the EU. Food Quality Preference 16:291304.

Witte, V.C., Krause, G.F. and Bailey, M.E. (1970). A new extraction method for determining 2- thiobarbituric acid values of pork and beef during storage. Journal of Food Science 35(5): 582-585.

Yadav AK, Kumar R, Priyadarshini L, Singh J (2018). Composition and medicinal properties of camel milk: A Review. Asian Journal of Dairy and Food Research 1; 34(2): 83-91.

\section{How to cite this article:}

Lokesh Tak, Basant Bais, Raghvendar Singh, Sanjay Singh and Nayak, T.C. 2018. Assessment of Probiotic and Neutraceutical Properties of Camel Milk Yoghurt. Int.J.Curr.Microbiol.App.Sci. 7(10): 3351-3357. doi: https://doi.org/10.20546/ijcmas.2018.710.388 